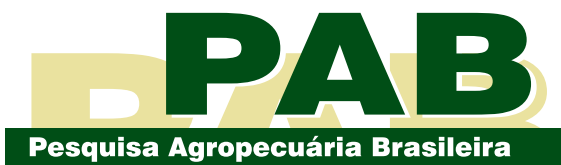

ISSN 1678-3921

Journal homepage: www.embrapa.br/pab

For manuscript submission and journal contents, access: www.scielo.br/pab
Pomology/ Original Article

\section{Yield, fruit quality, and survival of 'Pêra' sweet orange on eight rootstocks in tropical cohesive soils}

\begin{abstract}
The objective of this work was to determine the influence of eight rootstocks on the yield, fruit quality, and survival of 'Pêra CNPMF D6' sweet orange (Citrus sinensis) trees grown under rainfed conditions in a cohesive soil of the Brazilian Northeast. In 2014-2018, the yield, fruits, and survival of trees planted in 1997 were evaluated in a randomized complete block design. Yield was assessed using annual fruit production, yield efficiency, and the alternate bearing index. Tree survival was considered the percentage of plants that remained alive until 2018. Fruit quality was evaluated by physicochemical attributes. 'Cravo' confirmed its good yield performance. Despite the lower number of trees, the 'Mazoe' rough lemon rootstock induced the highest fruit yield. The 'Cravo' x 'Cleópatra' hybrid and 'Volkameriano' lemon favored the highest trees survival, whereas 'Indio' citrandarin and 'Cravo' lime resulted in intermediate levels. The 'San Diego' and 'Riverside' citrandarins induced shorter tree with a high yield efficiency and a higher alternate bearing index, respectively. Fruits with less juice and mass were induced, respectively, by 'Riverside' citrandarin and 'Volkameriano' lemon. It can be concluded that the 'Mazoe' rootstock induces a higher fruit yield and 'Cravo' x 'Cleópatra' and 'Volkameriano', a greater survival. In addition, all rootstocks, except 'Riverside' and 'Volkameriano', induce fruit that meet the minimum quality requirements.
\end{abstract}

Index terms: Citrus, Poncirus trifoliata, citrandarins, coastal tablelands, rainfed cultivation, scion/rootstocks combinations.

\section{Rendimento, qualidade do fruto e sobrevivência de laranjeiras 'Pêra' em oito porta-enxertos em solos tropicais coesos}

Resumo - O objetivo deste trabalho foi determinar a influência de oito portaenxertos no rendimento, na qualidade do fruto e na sobrevivência de laranjeiras (Citrus sinensis) 'Pêra CNPMF D6' cultivadas, em regime de sequeiro, em solo coeso do Nordeste brasileiro. Em 2014-2018, foram avaliados, no delineamento de blocos ao acaso, o rendimento, os frutos e a sobrevivência de árvores plantadas em 1997. O rendimento foi avaliado a partir da produção anual de frutos, da eficiência produtiva e do índice de alternância produtiva. A sobrevivência das árvores foi considerada a percentagem de plantas que permaneceram vivas até 2018. A qualidade dos frutos foi avaliada por meio de atributos físico-químicos. 'Cravo' confirmou seu bom desempenho produtivo. Apesar do menor número de árvores, o porta-enxerto limoeiro rugoso 'Mazoe' induziu a maior produtividade de frutos. O híbrido 'Cravo' x 'Cleópatra' e o limoeiro 'Volkameriano' favoreceram a maior sobrevivência das árvores, 
enquanto o citrandarin 'Indio' e o limoeiro 'Cravo' resultaram em níveis intermediários. Os citrandarins 'San Diego' e 'Riverside' induziram, respectivamente, árvores menores, com alta eficiência de produção e maior índice de alternância produtiva, respectivamente. Frutos com menos suco e massa foram induzidos, respectivamente, pelo citrandarin 'Riverside' e o limoeiro 'Volkameriano'. Concluise que o porta-enxerto 'Mazoe' induz maior rendimento de frutos e 'Cravo' x 'Cleópatra' e 'Volkameriano' maior sobrevivência. Além disso, todos os porta-enxertos, exceto 'Riverside' e 'Volkameriano', induzem frutos que atendem os requerimentos mínimos de qualidade.

Termos para indexação: Citrus, Poncirus trifoliata, citrandarins, tabuleiros costeiros, cultivo em sequeiro, combinações copa/porta-enxerto.

\section{Introduction}

Brazil holds about $23 \%$ of the world's production of sweet oranges [Citrus sinensis (L.) Osbeck] and more than half of its juice production (FAO, 2020). Throughout the country, 'Pêra' sweet orange, with mid-season maturity, is the most frequently grown variety, as it is suitable for both juice processing and fresh consumption (Carvalho et al., 2019b), and the most propagated rootstock for it has been 'Cravo' lime (Citrus limonia Osbeck) (Carvalho et al., 2019b; Conceição et al., 2019). Of the Brazilian regions, the Southeast is the major citrus-producing one, covering 468,563 ha $(71 \%)$, followed by the Northeast, with 108,527 ha $(16 \%)$ and a fruit production of $1,154,225$ tons $(6 \%)$ (IBGE, 2020).

In the Northeast, sweet oranges are mainly cultivated by smallholders under rainfed conditions in cohesive soils that are highly susceptible to seasonal drought, which contributes to low yields (Martins et al., 2016). About $90 \%$ of the citrus orchards in Northeastern Brazil use the combination of 'Pêra CNPMF D6' sweet orange grafted onto 'Cravo' lime (Prudente et al., 2004; Amorim et al., 2018). This rootstock has excellent agronomical characteristics, including the induction of early production and drought tolerance, but is susceptible to diseases such as citrus decline or blight and citrus sudden death, which reduce fruit yields and shorten orchard longevity (Pompeu Junior \& Blumer, 2019). For this reason, there is an increasing recognition of the risks posed by using a single rootstock for 'Pêra' sweet orange orchards (Sampaio et al., 2016; Amorim et al., 2018).
Recent studies conducted by Embrapa have shown the good performance of other rootstocks grafted on 'Pêra', such as some citrandarins [Citrus sunki (Hayata) hort. ex Tanaka x Poncirus trifoliata (L.) Raf.] (Schinor et al., 2013; Carvalho et al., 2016; Amorim et al., 2018; Conceição et al., 2019). Citrandarins usually confer resistance to diseases presented by mandarins and small-sized P. trifoliata trees (Pompeu Junior \& Blumer, 2009). Dwarfed trees are desirable because they allow a better inspection and control of pests and diseases, reduction of production costs, production of more fruits per canopy volume, and high planting densities (Pompeu Junior \& Blumer, 2009). Among citrandarins, 'Indio', 'Riverside', and 'San Diego' have been highlighted as rootstocks for rainfed sweet orange orchards in tropical cohesive soils of Northeastern Brazil (Carvalho et al., 2016; Amorim et al., 2018; Teodoro et al., 2020).

Despite the substantial body of knowledge on citrus rootstocks, there is relatively little information on their long-term survival (Sanderson \& Treeby, 2014), particularly in tropical cohesive soils (Prudente et al., 2004; Carvalho et al., 2019a). However, it is known that tropical trees grow, on average, two times faster than trees from temperate biomes and live for a significantly shorter time (Locosselli et al., 2020).

The objective of this work was to determine the influence of eight rootstocks on the yield, fruit quality, and survival of 'Pêra CNPMF D6' sweet orange trees grown under rainfed conditions in a cohesive soil of the Brazilian Northeast.

\section{Materials and Methods}

The study evaluated the influence of eight citrus rootstocks on the horticultural performance of 'Pêra CNPMF D6' sweet oranges from 17 to 21 years after planting in a tropical cohesive soil of the Brazilian Northeast.

The experiment was conducted in a commercial orchard of the cultivar, planted in 1997, in the municipality of Rio Real, in the north of the state of

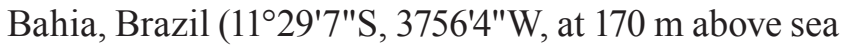
level). The local climate is As according to KöppenGeiger's classification, with a rainy season from April to September, followed by a dry summer. According to the historical series of 1998-2015, the average minimum, maximum, and median air temperatures 
for this municipality are, respectively, 20.70, 29.83, and $25.27^{\circ} \mathrm{C}$, and the average annual rainfall is 1,208 mm (Embrapa, 2019). From planting in 1997, rainfall was recorded daily using a rain gauge installed in the orchard, showing an average of $1,033 \mathrm{~mm}$ per year. The driest years were 2004, 2008, 2012, 2016, and 2018, with $885,907,639,942$, and $779 \mathrm{~mm}$, respectively, whereas the most humid were 1997 and 1999, with 1,530 and $1,415 \mathrm{~mm}$. The soil is a sandy clay loam, classified as an Argissolo Amarelo distrófico (Santos et al., 2018), i.e., an Ultisol (Soil Survey Staff, 2014).

In the experiment, the following eight rootstocks were evaluated: 'Mazoe' rough lemon (Citrus jambhiri Lush.), also known as 'African' rough lemon; 'Volkameriano' lemon (Citrus volkameriana Pasq.); 'Cravo' lime; 'BRS Maravilha' mandarin [Citrus sunki (Hayata) hort. ex Tanaka]; 'Indio', 'Riverside', and 'San Diego' citrandarins; and the 'Cravo' lime x 'Cleópatra' mandarin (Citrus reshni hort. ex Tanaka) hybrid. All commercial genotypes used are accessions of the citrus Genebank that were pre-selected by the citrus breeding program of Embrapa Mandioca e Fruticultura.

The trial was carried out in a randomized complete block design, with eight treatments (rootstocks), four replicates, and three trees per plot, spaced at 7.0x4.0 m (357 trees per hectare), without irrigation. Management practices included chemical fertilization, pest and weed control, as well as pruning. A soil sample collected prior to planting indicated: 0.57 $\mathrm{cmol}_{\mathrm{c}} \mathrm{dm}^{-3} \mathrm{Mg}, 0.25 \mathrm{cmol}_{\mathrm{c}} \mathrm{dm}^{-3} \mathrm{~K}$, and $0.18 \mathrm{cmol}_{\mathrm{c}} \mathrm{dm}^{-3}$ $\mathrm{Na}$, cation exchange capacity of $4.33 \mathrm{cmol}_{\mathrm{c}} \mathrm{dm}^{-3}$, and base saturation of $74.03 \%$. Soil acidity was corrected every two years by the application of dolomitic limestone. The orchard was fertilized annually based on soil analysis, using 2,400 g per plant of the $\mathrm{N}-\mathrm{P}_{2} \mathrm{O}_{5^{-}}$ $\mathrm{K}_{2} \mathrm{O}$ formula (20-0.5-12). In addition, foliar fertilizers were applied twice a year, supplying $8 \mathrm{~kg} \mathrm{Zn} 200 \mathrm{~L}^{-1}$, $6 \mathrm{~kg} \mathrm{Mg} 200 \mathrm{~L}^{-1}$, and $1 \mathrm{~kg} \mathrm{~B} 200 \mathrm{~L}^{-1}$. Pests, such as the citrus black fly Aleurocanthus woglumi Ashby (Hemiptera: Auchenorrhyncha: Aleyrodidae) and the leaf miner Phyllocnistis citrella Stainton (Lepidoptera: Gracillariidae), were controlled by spraying registered pesticides four times a year (Agrofit, 2019).

The effects of rootstocks on plant development and productive performance began to be assessed in 2014 when the orchards were 17 years old. Tree height (m) and canopy volume $\left(\mathrm{m}^{3}\right)$ were measured in 2017 according to Carvalho et al. (2019a). Fruit from all plants were counted and weighed in each harvest. With the data of yield and planting density, annual fruit yield $\left(\mathrm{Mg} \mathrm{ha}^{-1}\right)$ was estimated for each cultivar. Yield performance was evaluated through fruit yield, mean fruit yield, and fruit yield efficiency $\left(\mathrm{kg} \mathrm{m}^{-3}\right)$; the latter was recorded only in 2017 and estimated by the quotient between the production of fruits per plant (kilogram per tree), as in Teodoro et al. (2020). In addition, the alternate bearing index (ABI) was calculated based on the fruit yield recorded in 2014 and 2018, following the methodology of Carvalho et al. (2020). Survival rate (\%) was estimated in 2018 as the percentage of remaining plants in relation to initial planting density.

From 2014 to 2018, the mass of the fruits harvested annually was weighed and its mean value was estimated for each year. Fruit quality was evaluated using six fruits per plant harvested in 2015, the eighteenth year after planting, considering: fruit mass (g); juice content (\%); titratable acidity (TA, gram of citric acid per $100 \mathrm{~mL}$ of juice), measured by titration with $\mathrm{NaOH}$ $0.1 \mathrm{~N}$; total soluble solids (TSS, ${ }^{\circ}$ Brix), estimated by a refractometer; and vitamin $\mathrm{C}$ (mg of ascorbic acid per liter), measured by redox titration using iodate solution and the maturity index or the TSS/TA ratio. All these attributes were determined according to methodologies described in Carvalho et al. (2020) and Teodoro et al. (2020).

The univariate analysis of variance, followed by Scott-Knott's test, at 5\% probability, for grouping means was performed on all measured and estimated data. In addition, Fisher's discriminant analysis was also used to check whether or not the groups (rootstocks) differed from each other considering the set of all significant variables. The properties of each group were identified through these explanatory variables, which included plant height and canopy volume for tree size; average fruit yield, fruit yield efficiency, and ABI for production; and juice content and fruit mass for fruit quality. The following statistical packages were used: Real Statistics Resource Pack for the analysis of variance, DSAASTAT for Scott-Knott's test, and XLSTAT 2014 for the discriminant analysis, all add-ins for Excel. 


\section{Results and Discussion}

The smallest sweet orange trees were induced by 'San Diego' citrandarin, and the greatest ones by 'Mazoe' rough lemon (Table 1). Similar results were reported by Carvalho et al. (2016) for the 'BRS Piemonte' mandarin grafted onto 'San Diego'. The smaller size of the plants grafted onto 'San Diego' favors management practices and harvesting. Moreover, trees with a small canopy volume and high productive efficiency allow obtaining a high yield by increasing planting density.

All rootstocks induced annual fruit yields surpassing 18,000 kg ha ${ }^{-1}$ for 'Pêra CNPMF D6' 17 to 21 years after planting (Table 2). These numbers suggest that there was a higher yield in the eighteenth harvest regardless of the rootstock, followed by reductions in the other harvest years. However, the annual and average yields obtained in the present study are in line with those found for sweet oranges by Carvalho et al. (2019a).

'Mazoe' rough lemon induced the highest 'Pêra CNPMF D6' fruit yield throughout the harvests, surpassing in $28 \%$ those obtained on 'Cravo' lime (Table 2). These results are attributed to the largest

Table 1. Tree height $(\mathrm{TH})$, canopy volume (CV), and survival rate (SR) of 'Pêra CNPMF D6' sweet orange (Citrus sinensis) grafted onto eight rootstocks in the municipality of Rio Real, in the state of Bahia, Brazil ${ }^{(1)}$.

\begin{tabular}{lccc}
\hline Rootstock ${ }^{(2)}$ & $\mathrm{TH}(\mathrm{m})$ & $\mathrm{CV}\left(\mathrm{m}^{3}\right)$ & $\mathrm{SR}^{(3)}(\%)$ \\
\hline 'Mazoe' & $3.95 \mathrm{a}$ & $43.41 \mathrm{a}$ & 66 \\
'Cravo' & $3.18 \mathrm{~b}$ & $29.47 \mathrm{c}$ & 81 \\
'Indio' & $3.00 \mathrm{~b}$ & $28.60 \mathrm{c}$ & 81 \\
'BRS Maravilha' & $3.78 \mathrm{a}$ & $38.91 \mathrm{~b}$ & 69 \\
'Cravo' x 'Cleópatra' & $3.15 \mathrm{~b}$ & $27.22 \mathrm{c}$ & 91 \\
'Riverside' & $2.80 \mathrm{~b}$ & $24.52 \mathrm{c}$ & 78 \\
'San Diego' & $2.30 \mathrm{c}$ & $18.34 \mathrm{~d}$ & 78 \\
'Volkameriano' & $3.08 \mathrm{~b}$ & $24.62 \mathrm{c}$ & 91 \\
\hline Average & 3.15 & 29.38 & - \\
\hline CV (\%) & 7.30 & 10.70 & - \\
\hline
\end{tabular}

(1) Means followed equal letters do not differ by Scott-Knott's test, at 5\% probability. (2)'Mazoe' rough lemon, Citrus jambhiri; 'Cravo' lime, Citrus limonia; 'Indio', 'Riverside', and 'San Diego' citrandarins, Citrus sunki $\mathrm{x}$ Poncirus trifoliata; 'BRS Maravilha' mandarin, Citrus sunki; 'Cleópatra' mandarin, Citrus reshni; and 'Volkameriano' lemon, Citrus volkameriana. ${ }^{(3)}$ Data regarding the twenty-first year after planting of sweet orange trees. canopy volume and highest height of the trees induced by 'Mazoe' rough lemon (Table 1). These trees had a fruit yield efficiency similar to that on 'Cravo' lime, but lower than that on 'San Diego' (Table 2). The high fruit yield induced by 'Mazoe' rough lemon explains why some farmers in this region maintain this combination in their orchards despite great tree losses (Table 1). Likewise, Amorim et al. (2018) found a greater fruit yield in sweet oranges grafted onto Florida rough lemon than on 'Cravo' lime. Prudente et al. (2004) and Pompeu Junior \& Blumer (2019) also observed a high fruit yield when 'Pêra' sweet orange was grafted onto rough lemon.

'Cravo' lime induced high yields, although lower than those obtained with 'Mazoe' rough lemon, combined with a good regularity of production throughout the harvests (Table 2). The outstanding performance of 'Pêra' grafted onto 'Cravo' lime has also been highlighted in other studies carried out in Northeastern Brazil (Carvalho et al., 2016, 2019a; Martins et al., 2016) and in the state of São Paulo (Pompeu Junior \& Blumer, 2014).

From the seventeenth to the twenty-first year after planting, 'Indio' citrandarin induced relatively low fruit yields, in contrast to 'Cravo' lime and 'Mazoe' rough lemon (Table 2). These results differ from those reported by other authors for the same citrusproducing region in younger orchards (Carvalho et al., 2016; Sampaio et al., 2016. Amorim et al., 2018) and for the state of Acre, also in Brazil (Rodrigues et al., 2019). It should be pointed out that 'San Diego' citrandarin induced shorter trees, the lowest canopy volume (Table 1), and the highest fruit yield efficiency (Table 2). According to Schinor et al. (2013), hybrids involving the 'Cleópatra' and 'Sunki' mandarins, such as citrandarins, are good alternatives to 'Cravo' lime.

The present study showed variations in fruit yield throughout harvests. The highest yield was recorded in 2015 and the lowest in 2018 (Table 2). In short, low yields were observed after high production harvests. Girardi et al. (2017) and Silveira et al. (2020) reported similar variations in fruit production and suggested alternate bearing as one of the possible explanations. In this study, the rootstocks induced changes on the degree of alternate bearing, as indicated by the ABI, which ranged from 0.13 to 0.29 . Trees with a higher ABI also presented a lower fruit yield. The 
differences among scion/rootstock combinations were most pronounced in the trees grafted onto 'Riverside' citrandarin and 'Volkameriano' lemon. Silveira et al. (2020) evaluated the ABI in consecutive years for 'Pêra-IAC' sweet orange trees grafted onto 'Sunki' mandarin and found values similar to that of around 0.17 , which was obtained in the present study for 'Pêra CNPMF D6' grafted onto 'BRS Maravilha'. Pompeu Junior \& Blumer (2014) found the highest ABI to be around $0.22-0.23$ for trees grafted onto citrandarins. In addition, from $2014(1,023 \mathrm{~mm})$ to $2018(779 \mathrm{~mm})$, there was a decrease in rainfall, when the lowest fruit yield was verified for all trees. Girardi et al. (2017) suggested that the highest ABI would be related to trees with the highest drought tolerance. Therefore, alternate bearing may have contributed to the lower yields induced by 'Riverside' and, possibly, by 'Volkameriano'.

The trees on 'Mazoe' showed the lowest survival rate 21 years after planting (Table 1), despite being highly productive (Table 2). In contrast, the greatest tree survival was found for 'Pêra CNPMF D6' grafted onto 'Volkameriano' lemon and the 'Cravo' lime $\mathrm{x}$ 'Cleópatra' mandarin hybrid, with only $9 \%$ mortality (Table 1). Intermediate survival rates were obtained for trees grafted onto 'Indio' citrandarin and 'Cravo' lime, followed by those grafted onto the 'Riverside' and 'San Diego' citrandarins.

No noticeable disease symptoms were observed from the seventeenth to the twenty-first years after planting. Although the causes of tree mortality were not identified in this study, some researchers have reported symptoms of incompatibility between 'Pêra' sweet orange and rough lemons, including 'Mazoe' (Salibe et al., 2002). However, Mourão Filho et al. (1991), Prudente et al. (2004), and Pompeu Junior \& Blumer (2019) found no symptoms of graft incompatibility between the 'Pêra' sweet orange scion and the rough lemon rootstock.

The symptoms leaf brightness loss, chlorosis, and leaf fall, including stem dieback and tree death, have usually been verified in sweet orange trees grown in the Brazilian Northeast. It is well known that the 'Cravo' lime and 'Volkameriano' rough lemon rootstocks are highly susceptible to citrus decline, while the 'Cleópatra' and 'Sunki' mandarins would be asymptomatic (Mourão Filho et al., 1991). The high survival of trees grafted onto 'Volkameriano' might be related to a relatively good resistance to Phytophthora root rot, a common disease in the Brazilian Northeast (Salibe \& Cereda, 1984).

Table 2. Annual and mean fruit yield (FY), from the seventeenth to the twenty-first harvests (2014-2018), fruit yield efficiency (FYE), and alternate bearing index (ABI) for 'Pêra CNPMF D6' sweet orange (Citrus sinensis) grafted onto eight rootstocks in the municipality of Rio Real, in the state of Bahia, Brazil ${ }^{(1)}$.

\begin{tabular}{|c|c|c|c|c|c|c|c|c|}
\hline \multirow[t]{2}{*}{ Rootstock $^{(2)}$} & \multicolumn{6}{|c|}{ Annual fruit yield $\left(\mathrm{kg} \mathrm{ha}^{-1}\right)$} & \multirow{2}{*}{$\begin{array}{c}\text { FYE } \\
\left(\mathrm{kg} \mathrm{m}^{-3}\right)\end{array}$} & \multirow[t]{2}{*}{$\mathrm{ABI}$} \\
\hline & $17^{\text {th }}$ & $18^{\text {th }}$ & $19^{\text {th }}$ & $20^{\text {th }}$ & $21^{\text {st }}$ & Mean & & \\
\hline 'Mazoe' & $53.18 \mathrm{a}$ & $60.63 a$ & $47.22 \mathrm{a}$ & $62.08 \mathrm{a}$ & $27.29 \mathrm{a}$ & $50.08 \mathrm{a}$ & $55.75 b$ & $0.18 \mathrm{~b}$ \\
\hline 'Cravo' & $39.05 b$ & $48.81 \mathrm{~b}$ & $40.56 \mathrm{~b}$ & $29.46 \mathrm{c}$ & $22.06 \mathrm{~b}$ & $35.99 b$ & $63.51 \mathrm{~b}$ & $0.13 b$ \\
\hline 'Indio' & $35.27 \mathrm{~b}$ & $50.12 b$ & $30.13 d$ & $27.92 \mathrm{c}$ & $20.69 b$ & $32.83 \mathrm{c}$ & $51.15 \mathrm{c}$ & $0.16 \mathrm{~b}$ \\
\hline 'BRS Maravilha' & $33.38 \mathrm{~b}$ & $48.33 b$ & $31.09 \mathrm{~d}$ & $28.92 \mathrm{c}$ & $18.97 \mathrm{~b}$ & $32.14 \mathrm{c}$ & $36.60 \mathrm{c}$ & $0.17 b$ \\
\hline 'Cravo' x 'Cleópatra' & $31.75 b$ & $45.77 \mathrm{c}$ & $32.28 \mathrm{~d}$ & $27.83 \mathrm{c}$ & $19.29 \mathrm{~b}$ & $31.39 \mathrm{c}$ & $51.25 \mathrm{c}$ & $0.15 b$ \\
\hline 'Riverside' & $19.73 b$ & $49.52 b$ & $30.63 \mathrm{~d}$ & $37.18 \mathrm{~b}$ & $18.08 \mathrm{~b}$ & $31.03 \mathrm{c}$ & $61.91 b$ & $0.29 \mathrm{a}$ \\
\hline 'San Diego' & $26.87 b$ & $41.22 \mathrm{~d}$ & $36.04 \mathrm{c}$ & $26.44 \mathrm{c}$ & $20.01 b$ & $30.11 \mathrm{c}$ & $105.69 \mathrm{a}$ & $0.16 \mathrm{~b}$ \\
\hline 'Volkameriano' & $28.78 b$ & $52.43 b$ & $22.57 \mathrm{e}$ & $26.27 \mathrm{c}$ & $19.01 \mathrm{~b}$ & $29.81 \mathrm{c}$ & $44.37 \mathrm{c}$ & $0.23 \mathrm{a}$ \\
\hline Average & 32.99 & 49.31 & 33.29 & 31.80 & 20.47 & 34.17 & 57.78 & 0.18 \\
\hline CV (\%) & 21.89 & 6.21 & 9.08 & 15.38 & 14.38 & 6.56 & 16.42 & 28.97 \\
\hline
\end{tabular}

${ }^{(1)}$ Means followed by equal letters do not differ by Scott-Knott's test, at 5\% probability. (2)'Mazoe' rough lemon, Citrus jambhiri; 'Cravo' lime, Citrus limonia; 'Indio', 'Riverside', and 'San Diego' citrandarins, Citrus sunki x Poncirus trifoliata; 'BRS Maravilha' mandarin, Citrus sunki; 'Cleópatra' mandarin, Citrus reshni; and 'Volkameriano' lemon, Citrus volkameriana. 
Regarding fruit quality, the fruits induced by most of the rootstocks had a similar juice content, which was the lowest for those produced by trees on 'Riverside' citrandarin (Table 3). None of the rootstocks induced significant differences regarding TSS, ascorbic acid contents (vitamin C), TA, and fruit mass (Table 3). However, considering the average of the five last harvests from the seventeenth to twenty-first year after planting, the lowest fruit mass was induced by 'Volkameriano' lemon. The TSS/TA ratio of the fruits was between 12.56 and 14.80 (Table 3). According to Volpe et al. (2002), juice processing industries have a preference for fruits with a TSS/TA ratio equal to or greater than 13, in Florida, USA, and equal to or greater than 12 in Brazil. The relationship between TSS and TA expresses the balance between these components in juice, giving it its flavor (Couto et al., 2010). Therefore, the fruits of the studied cultivar meet the minimum quality requirements for both the fresh fruit market (Ceagesp, 2011) and industry (TSS/ TA ratio equal to or greater than 12), irrespectively of the used rootstock.

Fisher's discriminant analysis showed that the differences between the uncorrelated discriminant vectors for the different rootstocks were significant by Wilks' lambda test $(\mathrm{p}<0.0001)$. Three distinct groups were obtained, formed by (1) 'Mazoe' rough lemon, (2) 'San Diego' citrandarin, and (3) the other six rootstocks. 'Mazoe' rough lemon induced tall and bulky trees with a higher mean fruit yield, as can be deduced by projecting the observations cloud (Figure 1 A) on the correlation circle (Figure 1 B). Contrastingly, 'San Diego' citrandarin showed, as main properties, a high yield efficiency associated with shorter trees with a low canopy volume, which makes them more suitable for high-density plantings. The other six rootstocks, including 'Cravo' lime, did not differ from each other considering the score of quantitative predictor variables.

The correlation circle (Figure $1 \mathrm{~B}$ ) also shows that Factor 1 discriminated over $75 \%$ of variability, and that this factor is associated with tree height, canopy volume, and the mean yield of the five experimental years. On its side, more than $13 \%$ of variability was attributed to Factor 2, with yield efficiency as the most important variable. Factors 1 and 2, together, were able to discriminate $89 \%$ of total variability. The multiple correlation analysis revealed that tree height, canopy volume, and mean fruit yield were significant and positively correlated, while yield efficiency showed a negative correlation with these explanatory variables.

Table 3. Fruit quality of 'Pêra CNPMF D6' sweet orange (Citrus sinensis) grafted onto eight rootstocks in the municipality of Rio Real, in the state Bahia, Brazil ${ }^{(1)}$.

\begin{tabular}{|c|c|c|c|c|c|c|c|}
\hline \multirow[t]{2}{*}{ Rootstock $^{(2)}$} & \multicolumn{2}{|c|}{ Fruit mass (g) } & \multirow{2}{*}{$\begin{array}{c}\text { Juice content } \\
(\%)\end{array}$} & \multirow{2}{*}{$\begin{array}{c}\text { Vitamin C } \\
(\mathrm{mg} \text { per } 100 \\
\mathrm{mL})\end{array}$} & \multirow{2}{*}{$\begin{array}{c}\text { TSS } \\
\left({ }^{\circ} \text { Brix }\right)\end{array}$} & \multirow{2}{*}{$\begin{array}{c}\text { TA } \\
\text { (g of citric acid } \\
\text { per } 100 \mathrm{~mL} \text { ) }\end{array}$} & \multirow[t]{2}{*}{ TSS/TA } \\
\hline & 2014-2018 & 2015 & & & & & \\
\hline 'Riverside' & $168.75 \mathrm{a}$ & 221.24 & $59.59 \mathrm{~b}$ & 44.91 & 11.55 & 0.77 & 14.79 \\
\hline 'Indio' & $168.25 \mathrm{a}$ & 219.29 & $64.99 \mathrm{a}$ & 41.67 & 10.80 & 0.73 & 14.80 \\
\hline 'BRS Maravilha' & $171.88 \mathrm{a}$ & 212.69 & $62.23 \mathrm{a}$ & 44.91 & 11.18 & 0.77 & 14.75 \\
\hline 'Volkameriano' & $153.31 \mathrm{~b}$ & 218.15 & $64.06 \mathrm{a}$ & 46.57 & 10.98 & 0.77 & 14.20 \\
\hline 'Cravo' x 'Cleópatra' & $167.38 \mathrm{a}$ & 214.59 & $64.19 \mathrm{a}$ & 43.36 & 10.63 & 0.76 & 14.12 \\
\hline 'Mazoe' & $174.56 \mathrm{a}$ & 214.85 & $63.09 \mathrm{a}$ & 46.35 & 10.58 & 0.88 & 13.75 \\
\hline 'San Diego' & $169.75 \mathrm{a}$ & 217.22 & $62.84 \mathrm{a}$ & 43.35 & 10.93 & 0.83 & 13.46 \\
\hline 'Cravo' & $171.69 \mathrm{a}$ & 214.45 & $62.94 \mathrm{a}$ & 46.25 & 10.98 & 0.73 & 12.56 \\
\hline Average & 168.19 & 216.56 & 63.01 & 44.50 & 10.95 & 0.78 & 14.18 \\
\hline CV (\%) & 4.15 & 4.84 & 2.55 & 5.88 & 4.85 & 11.68 & 10.29 \\
\hline
\end{tabular}

${ }^{(1)}$ Means followed by equal letters do not differ by Scott-Knott's test, at 5\% probability. (2)'Mazoe' rough lemon, Citrus jambhiri; 'Cravo' lime, Citrus limonia; 'Indio', 'Riverside', and 'San Diego' citrandarins, Citrus sunki x Poncirus trifoliata; 'BRS Maravilha' mandarin, Citrus sunki; 'Cleópatra' mandarin, Citrus reshni; and 'Volkameriano' lemon, Citrus volkameriana. TSS, total soluble solids content; and TA, titratable acidity. 

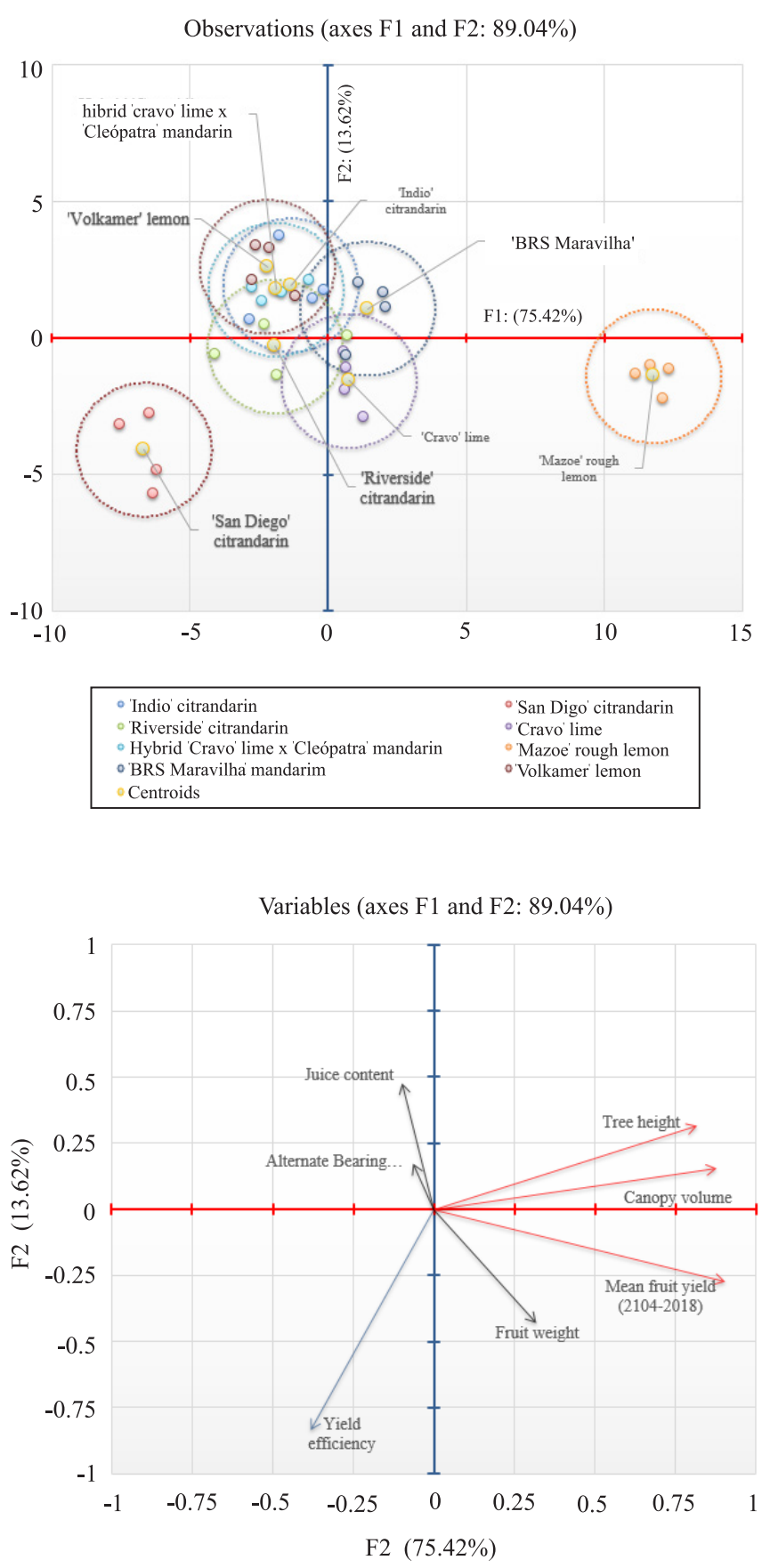

Figure 1. Graphical representation of Fisher's discriminant analysis of eight rootstocks onto which 'Pêra CNPMF D6' sweet orange (Citrus sinensis) was grafted in the municipality of Rio Real, in the state of Bahia, Brazil. A, observation cloud with confidence circles for the groups in the space of the two main factors (F1 and F2); and B, correlation circle obtained by Fisher's discriminant analysis. Red arrows, variables mostly correlated with Factor 1; blue arrow, variable mostly correlated with Factor 2; and black arrows, variables associated with other factors.

\section{Conclusions}

1. The 'Mazoe' rough lemon (Citrus jambhiri) rootstock induces the highest fruit yield for 'Pêra CNPMF D6' sweet orange (Citrus sinensis), even 21 years after planted under rainfed conditions in a cohesive soil of the Brazilian Northeast.

2. The 'Cravo' x 'Cleópatra' mandarin (Citrus limonia x Citrus reshni) hybrid and 'Volkameriano' lemon (Citrus volkameriana) induce a higher survival rate for 'Pêra CNPMF D6' at 21 years and a fruit yield as high as that obtained on 'Cravo' lime.

3. Except for 'Riverside' citrandarin (Citrus sunki $\mathrm{x}$ Poncirus trifoliata) and 'Volkameriano' lemon, all rootstocks induce 'Pêra CNPMF D6' fruits that meet the minimum quality requirements of the market and industry.

\section{Acknowledgments}

To Citricultura Maratá Ltda. and its agronomist Luiz Jacson Lemos de Carvalho, for allowing us to conduct the study in their farm and for field support.

\section{References}

AGROFIT. Sistemas de Agrotóxicos Fitossanitários. Available at: <http://agrofit.agricultura.gov.br/agrofit_cons/principal_ agrofit_cons $>$. Accessed on: Dec. 32019.

AMORIM, M. da S.; GIRARDI, E.A.; FRANÇA, N. de O.; GESTEIRA, A. da S.; SOARES FILHO, W. dos S.; PASSOS, O.S. Initial performance of alternative citrus scion and rootstock combinations on the northern coast of the state of Bahia, Brazil. Revista Brasileira de Fruticultura, v.40, e-480, 2018. DOI: https://doi.org/10.1590/0100-29452018480.

CARVAlHO, H.W.L. de; TEODORO, A.V.; BARROS, I. de; CARVALHO, L.M. de; SOARES FILHO, W. dos S.; GIRARDI, E.A.; PASSOS, O.S.; PINTO-ZEVALLOS, D.M. Rootstockrelated improved performance of 'Pera' sweet orange under rainfed conditions of Northeast Brazil. Scientia Horticulturae, v.263, art.109148, 2020. DOI: https://doi.org/10.1016/j. scienta.2019.109148.

CARVALHO, L.M. de; CARVALHO, H.W.L de; SOARES FILHO, W. dos S.; MARTINS, C.R.; PASSOS, O.S. Portaenxertos promissores, alternativos ao limoeiro 'Cravo', nos Tabuleiros Costeiros de Sergipe. Pesquisa Agropecuária Brasileira, v.51, p.132-141, 2016. DOI: https://doi.org/10.1590/ S0100-204X2016000200005.

CARVALHO, L.M. de; CARVALHO, H.W.L. de; BARROS, I. de; MARTINS, C.R.; SOARES FILHO, W. dos S.; GIRARDI, E.A.; PASSOS, O.S. New scion-rootstock combinations for diversification of sweet orange orchards in tropical hardsetting 
soils. Scientia Horticulturae, v.243, p.169-176, 2019a. DOI: https://doi.org/10.1016/j.scienta.2018.07.032.

CARVALHO, S.A. de; GIRARDI, E.A.; MOURÃO FILHO, F. de A.A.; FERRAREZI, R.S.; COLETTA FILHO, H.D. Advances in citrus propagation in Brazil. Revista Brasileira de Fruticultura, v.41, e-422, 2019b. DOI: https://doi.org/10.1590/010029452019422 .

CEAGESP. Companhia de Entrepostos e Armazéns Gerais de São Paulo. Normas de classificação de citros de mesa. São Paulo: CEAGESP, 2011. Available at: <http://www.ceagesp.gov.br/wpcontent/uploads/2015/07/citros.pdf >. Accessed on: Aug. 112020.

CONCEIÇÃO, P.M. da; AZEVEDO, F.A. de; ECKER, G.V.; MORELLI, M.; CRISTOFANI-YALY, M. Physiological quality of citrandarins, Poncirus trifoliata and Sunki mandarin seeds. Comunicata Scientiae, v.10, p.461-466, 2019. DOI: https://doi.org/10.14295/cs.v10i4.3138.

COUTO, M.A.L.; CANNIATTI-BRAZACA, S.G. Quantificação de vitamina $\mathrm{C}$ e capacidade antioxidante de variedades cítricas. Ciência e Tecnologia de Alimentos, v.30, p.15-19, 2010. Supl.1. DOI: https://doi.org/10.1590/S0101-20612010000500003.

EMBRAPA. GeoTc: organização e disponibilização da informação geoespacial sobre recursos naturais e aspectos socioeconômicos da área de atuação da Embrapa Tabuleiros Costeiros. 2019. Available at: <http://geotc.cpatc.embrapa.br>. Accessed on: Jan. 112021.

FAO. Food and Agriculture Organization of the United Nations. Faostat: crops. Available at: <http://www.fao.org/faostat/ en/\#data/QC/visualize>. Accessed on: July 232020.

GIRARDI, E.A.; CERQUEIRA, T.S.; CANTUARIASAVILÉS, T.E.; SILVA, S.R da; STUCHI, E.D. Sunki mandarin and Swingle citrumelo as rootstocks for rain-fed cultivation of late-season sweet Orange selections in northern São Paulo state, Brazil. Bragantia, v.76, p.501-511, 2017. DOI: https://doi. org/10.1590/1678-4499.2016.350.

IBGE. Instituto Brasileiro de Geografia e Estatística. Levantamento sistemático da produção agrícola. Available at: <https://sidra.ibge.gov.br/tabela/6588>. Accessed on: April 23 2020.

LOCOSSELLI, G.M.; BRIENEN, R.J.W.; LEITE, M. de S.; GLOOR, M.; KROTTENTHALER, S.; OLIVEIRA, A.A. de; BARICHIVICH, J.; ANHUF, D.; CECCANTINI, G.; SCHÖNGART, J.; BUCKERIDGE, M. Global tree-ring analysis reveals rapid decrease in tropical tree longevity with temperature. PNAS, v.29, p.33358-33364, 2020. DOI: https://doi.org/10.1073/ pnas. 2003873117.

MARTINS, C.R.; CARVALHO, H.W.L. de; TEODORO, A.V.; SOARES FILHO, W. dos S.; PASSOS, O.S. Agronomical performance of citrus scion cultivars grafted on Rangpur lime in north-eastern Brazil. Australian Journal of Crop Science, v.10, p.16-23, 2016.

MOURÃO FILHO, F. de A.A.; MISCHAN, M.M.; SALIBE, A.A. Efeito de diferentes porta-enxertos no vigor e produtividade da laranjeira 'Pera' (Citrus sinensis L.) Osbeck. Anais Esalq, v.48, p.167-184, 1991. DOI: https://doi.org/10.1590/S007112761991000100010 .
POMPEU JUNIOR, J.; BLUMER, S. Comportamento de porta-enxertos em área afetada pela morte súbita dos citros. Citrus Research and Technology, v.40, e1048, 2019. DOI: https://doi.org/10.4322/crt.18319.

POMPEU JUNIOR, J.; BLUMER, S. Híbridos de trifoliata como porta-enxertos para a laranjeira 'Valência'. Pesquisa Agropecuária Brasileira, v.44, p.701-705, 2009. DOI: https://doi.org/10.1590/S0100-204X2009000700008.

POMPEU JUNIOR, J.; BLUMER, S. Híbridos de trifoliata como porta-enxertos para laranjeira Pêra. Pesquisa Agropecuária Tropical, v.44, p.9-14, 2014. DOI: https://doi.org/10.1590/S198340632014000100007.

PRUDENTE, R.M.; SILVA, L.M.S. da; CUNHA SOBRINHO, A.P. da. Comportamento da laranjeira 'Pêra' sobre cinco portaenxertos em ecossistema de tabuleiros costeiros, Umbaúba - SE. Revista Brasileira de Fruticultura, v.26, p.110-112, 2004. DOI: https://doi.org/10.1590/S0100-29452004000100030.

RODRIGUES, M.J. da S.; ARAÚJO NETO, S.E. de; ANDRADE NETO, R. de C.; SOARES FILHO, W. dos S.; GIRARDI, E.A.; LESSA, L.S.; ALMEIDA, U.O. de; ARAÚJO, J.M. de. Agronomic performance of the 'Pera' orange grafted onto nine rootstocks under the conditions of Rio Branco, Acre, Brazil. Revista Brasileira de Ciências Agrárias, v.14, e6642, 2019. DOI: https://doi.org/10.5039/agraria.v14i4a6642.

SALIBE, A.A.; CEREDA, E. Limitations on the use of Volkamer lemon as rootstock for citrus. In: INTERNATIONAL ORGANIZATION OF CITRUS VIROLOGISTS CONFERENCE, 9., 1984, Riverside. Proceedings. Riverside: IOCV, 1984. p.371374.

SALIBE, A.A.; TEÓFILO SOBRINHO, J.; MÜLLER, G.W. Sinopse de conhecimentos e pesquisas sobre a laranja 'Pêra'. Laranja, v.23, p.231-245, 2002.

SAMPAIO, A.H.R.; COELHO FILHO, M.A.; SOUZA, L.D.; BRITO, R.B.F.; SILVA, R.O. da. Yield and quality of 'Pera' sweet orange grafted on different rootstocks under rainfed conditions. Revista Brasileira de Fruticultura, v.38, e.770, 2016. DOI: https://doi.org/10.1590/0100-29452016770.

SANDERSON, G.P.; TREEBY, M.T. Fruit yield of common orange varieties in south-east Australia: initial evaluation versus long term performance. Scientia Horticulturae, v.180, p.111-117, 2014. DOI: https://doi.org/10.1016/j.scienta.2014.10.009.

SANTOS, H.G. dos; JACOMINE, P.K.T.; ANJOS, L.H.C. dos; OLIVEIRA, V.Á. de; LUMBRERAS, J.F.; COELHO, M.R.; ALMEIDA, J.A. de; ARAÚJO FILHO, J.C. de; OLIVEIRA, J.B. de. CUNHA, T.J.F. Sistema brasileiro de classificação de solos. 5.ed. rev. e ampl. Brasília: Embrapa, 2018. 356p.

SCHINOR, E.H.; CRISTOFANI-YALY, M.; BASTIANEL, M.; MACHADO, M.A. Sunki mandarin vs Poncirus trifoliata hybrids as rootstocks for Pera sweet orange. Journal of Agricultural Science, v.5, p.190-200, 2013. DOI: https://doi.org/10.5539/jas. v5n6p190.

SILVEIRA, L.K.; PAVÃO, G.C.; DIAS, C.T. dos S.; QUAGGIO, J.A.; PIRES, R.C. de M. Deficit irrigation effect on fruit yield, quality and water use efficiency: a long-term study on Pêra-IAC sweet orange. Agricultural Water Management, 
v.231, art.106019, 2020. DOI: https://doi.org/10.1016/j. agwat.2020.106019.

SOIL SURVEY STAFF. Keys to soil taxonomy. 12th ed. Washington: USDA, 2014. 360p.

TEODORO, A.V.; CARVALHO, H.W.L. de; BARROS, I. de; CARVALHO, L.M. de; MARTINS, C.R.; SOARES FILHO, W. dos S.; GIRARDI, E.A.; PASSOS, O.S. Performance of 'Jaffa' sweet orange on different rootstocks for orchards in the
Brazilian Northeast. Pesquisa Agropecuária Brasileira, v.55, e01665, 2020. DOI: https://doi.org/10.1590/S1678-3921.pab2020. v55.01665.

VOLPE, C.A.; SCHÖFFEL, E.R.; BARBOSA, J.C. Influência da soma térmica e da chuva durante o desenvolvimento de laranjas 'Valência' e 'Natal' na relação entre sólidos solúveis e acidez e no índice tecnológico do suco. Revista Brasileira de Fruticultura, v.24, p.436-441, 2002. DOI: https://doi.org/10.1590/S010029452002000200031 . 